\title{
The comparison attachment styles and Alexithymia in suicidal attempts and control group
}

\author{
Maryam Ghorbani ${ }^{1}$, Maryam Najafi ${ }^{2}$ \\ 1-Assist.prof, Department psychology, Payam Noor University, Tehran, Iran (Corresponding Author). \\ E-mail: ma.najafi20016@gmail.com \\ 2- M.A in General Psychology, Payam Noor University, Tehran, Iran.
}

Received: 23/11/2019 Accepted: 09/03/2020

\begin{abstract}
Introduction: Suicide can be defined as a conscious act of self-harm that leads to death.

Aim: The aim of this study was to comparison attachment styles and alexithymia in suicidal attempts and control group.

Method: In this casual comparative study, 100 individuals (50 suicide attempts and 50 normal individuals) were selected by convenience sampling. All participant completed the attachment styles questionnaire and Toronto emotional alexithymia scale. Data were analyzed using MANOVA by SPSS-21.

Results: The results showed that the difference between two groups was significant in difficulty in regulating emotions. Also, the difference between the two groups in avoidant and secure attachment style is significant $(\mathrm{p}<0.05)$.

Conclusion: According to result, it can be argued that interpersonal and emotional factors play a meaningful role in suicide. It seems that interpersonal factor and emotional characteristic should be considered in planning for prevention and treatment of suicide.
\end{abstract}

Keywords: Attachment styles, Affective symptoms, Suicide

How to cite this article : Ghorbani M, Najafi M. The comparison attachment styles and Alexithymia in suicidal attempts and control group. Shenakht Journal of Psychology and Psychiatry. 2020; 7 (1): 30-42 .URL: http://shenakht.muk.ac.ir/article-1-655-fa.pdf

Copyright ( $\odot 2018$ the Author (s). Published by Kurdistan University of Medical Sciences. This is an open access article distributed under the terms of the Creative Commons Attribution-Non Commercial License 4.0 (CCBY-NC), where it is permissible to download, share, remix, transform, and buildup the work provided it is properly cited. The work cannot be used commercially without permission from the journal. 


\title{
مقايسه سبكهاى دلبستكى و ناكويى هيجانى بين اقدام كنندكان به خودكشى و افراد كروه كنترل
}

\author{
مريم قربانى '، مريم نجفى

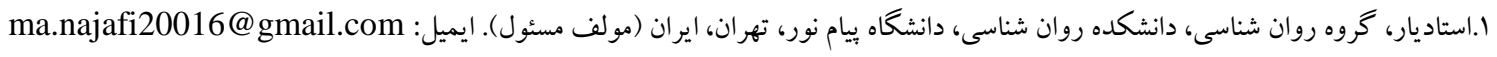

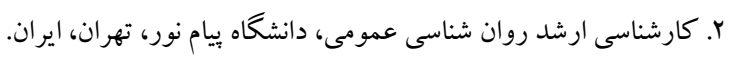

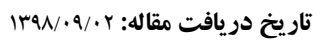

\section{جكيده}

مقدمه: خود كشى را مى توان به عنوان اقدامى آكاهانه در خود آزارى تعريف نمود كه به مر گك منتهى مى گردد. هدف: هدف يُوهش حاضر مقايسه سبكهاى دلبستگى و ناكويى هيجانى در بيماران اقدام كننده به خود كشى و افراد بهنجار است. روش: به همين منظور، در يكك مطالعه على مقايسهاى از بين كليه افراد اقدام كننده به خود كشى و افراد عادى شهرستان گنبد، به روش

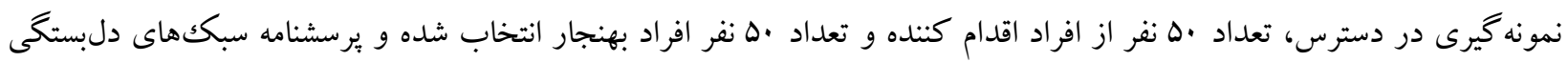

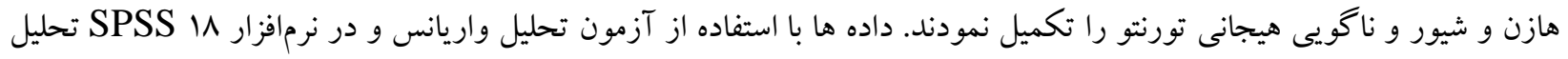

يافتها: نتايج نشان داد كه در بعد دشوارى در تنظيم هيجانات در ناگويى هيجانى تفاوت بين دو گروه معنادار است. همجِين تفاوت

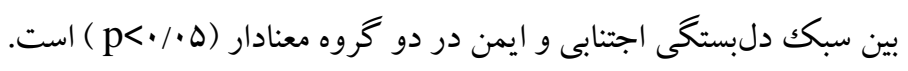

نتيجه كيرى: بر اساس يافته ها مى توان بيان كرد نقص در بيان و تشخيص احساسات در رفتارهاى برخطر از جمله خودكشى مؤثر

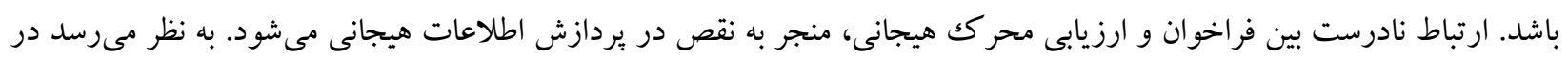

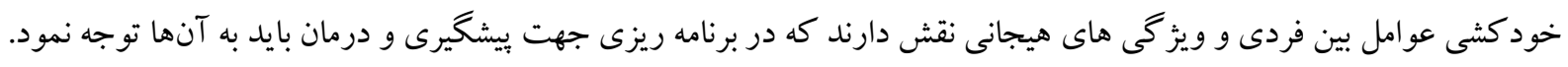
كليد وازهها: سبك هاى دلبستخى، ناگويى هيجانى، خود كشى 
اضطراب، برخاشگرى، اختلالات سايكوتيك و ساير مقدمه

اختلالات شخصيتى است (هيزمن و همكاران، ·. (Y). يزوهش ها نشان داده است كه ويز گیى هاى شخصيتى

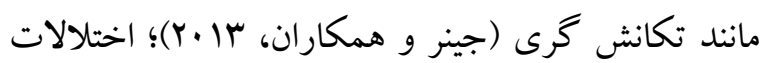

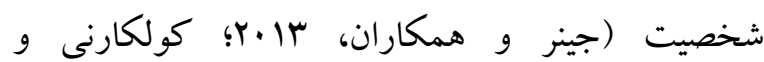

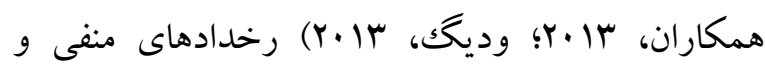

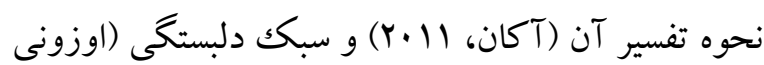

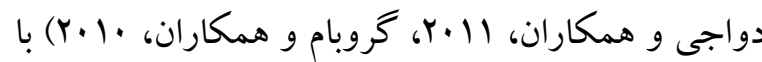
خودكشى مرتبط هستند. بر اساس نظريات بالبى، دلبستخى به معناى بيوند عاطفى است كه در كودكى،

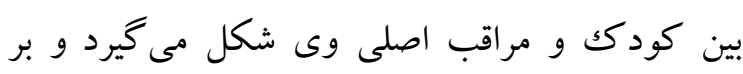
رشد اجتماعى و احساس كودكى در كل زندكى مؤثر

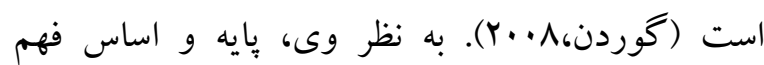

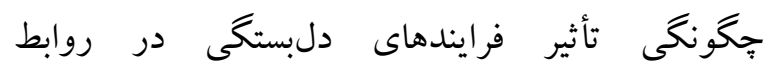
بزرگكسالى است و علت اصلى تداوم و بيوستخى بين تجارب دلبستكى اوليه با شناختها، احساسات و رفتارها

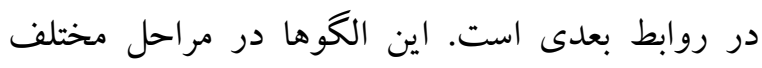
رشد- آكاهانه و نآكاهانه (عمدتاً نآكاهانه)- در سطح روابط ميان فردى تعميم يافته، نقش مهمى در شكل گيرى شناخت ها، عواطف و رفتارهاى ما بازى كرده و معمولاً در مقابل اصلاح و تغيير مقاوماند (رمضانى، اسفندآباد،

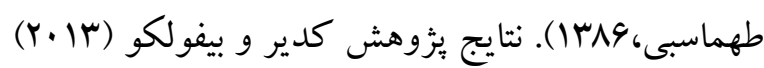
و جونز و همكاران (F) (Y) نشان داده وجود هر نوع سبك دلبستگى نايمن با افسردگى يككساله و افكار

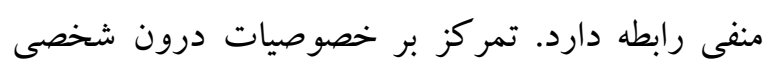
به عنوان بررسى علل بيامدها از جمله خود كشى بيشتر بر

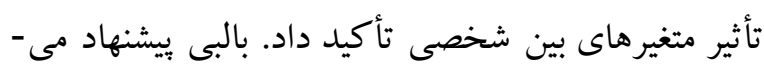

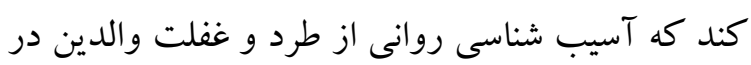
دوران كودكى ظاهر مىشود. نو روان تحليل گران مدل خود كشى يكك مسئله مهرم بهداشت عمومى است و در برخى از كشورها هشتمين علت مرگك در افراد بزرگكسال است. در سطح جهان روزانه .... نفر در اثر خودكشى

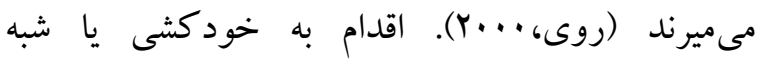
خود كشى • \- ^ برابر شايعتر از موارد خودكشى است

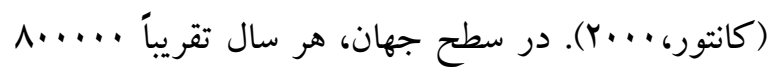

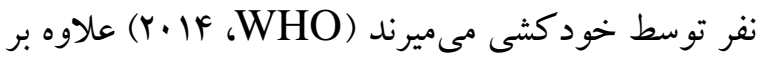
اين، شيوع طول عمر خودكشى در ارويا ه/4ه درصد

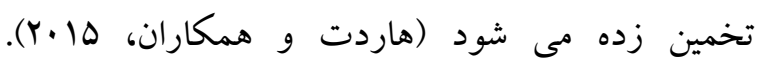
خودكشى شايعترين علت مركَ براى مردان در سنين r Fq-r. (Y.19) و تخمين زده مى شود كه يكك نفر در وانزده

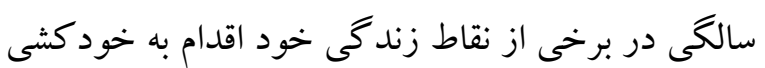
كرده باشد (مكمنوس،19 1Y). علاوه بر اين، شيوع زندكى ايده آل خودكشى در ارويا ه/ه درصد تخمين زده مى شود (هاردت و همكاران، ها +Y). در حال حاضر خودكشى دهمين عامل اصلى مرگك در ايالات متحده

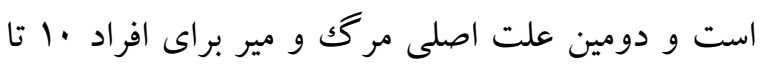

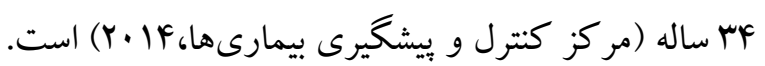
در تبيين خودكشى، گروهى صاحب نظر به ساختارهاى

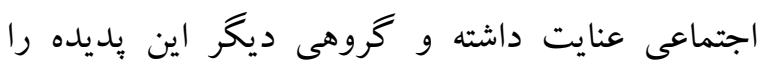
بركرفته از مسائل فردى و روانى دانسته اند (كلدى و

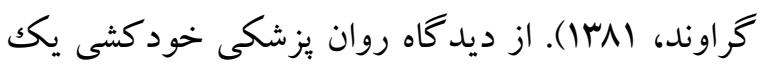
بيمارى روانى است كه ريشهى آن را بايد در ساير بيمارىهاى روانى جستجو كرد. در عين حال كه خود كشى خود يكى از نشانه هاى اختلالات روانى است

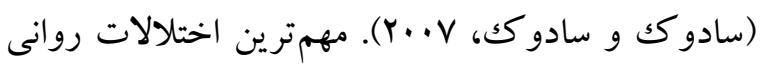
كه با خود كشى ارتباط بيشترى دارند شامل افسردگى، 
به نظر مى رسد كه سبك دلبستگى با مشكلات هيجانى

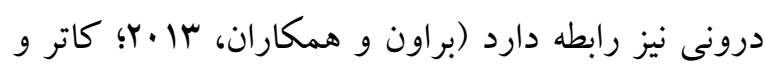

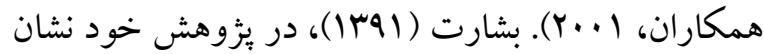
داد كه بين ناگويى هيجانى با سبك دلبستگى ايمن رابطه منفى و با سبككهاى دلبستگى اجتنابى و دوسو گرا رابطه مثبت است و مكانيسمهاى دفاعى در رابطه بين سبك هاى دلبستخى و ناكويى هيجانى تأثير واسطهاى دارد؛ بنابراين از عوامل درون شخصى مهم ديخر در اختلالات هيجانى و رفتارى مى توان به الكسى تيميا يا ناكويى هيجانى اشاره كرد. ناكويى هيجانى يكك مفهوم

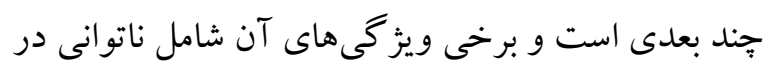
به كار گيرى احساسات، مشكلات هيجانى، تفكر انتقادى در مورد واقعيتهاى كم اهميت بيرونى، كاهش ياد آورى رؤياها، دشوارى در تمايز بين حالتهاى هيجانى و حس هاى بدنى، فقدان جلوههاى عاطفى جهره، ظرفيت محدود براى همدلى و خودآكاهى و نارسايى در تنظيم مديريت

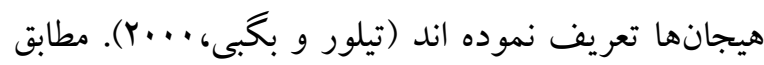
با رويكرد صفت مدار، دستهاى از بزّوهشها ثبات زمانى نارسايى هيجانى را مورد ترديد قرار دادهاند و آن را به

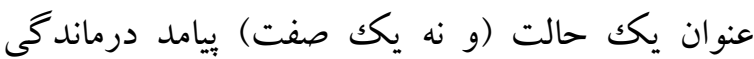
شخصى معرفى كردهاند. بر اساس اين رويكرد، نارسايى له له هيجانى صرفاً يكك مكانيسم مقابلهاى براى محافظت از خود عليه درماندگى هيجانى مرتبط با موقعيتهاى شديداً

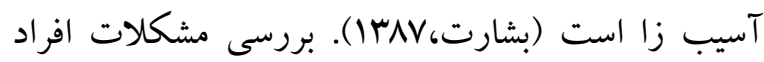
مبتلا به ناكويى هيجانى در حوزههاى بين فردى و روابط با ديخران، در سال هاى اخير مورد توجه محققان قرار كرفته است. در اين راستا، مونت باروكى و همكاران

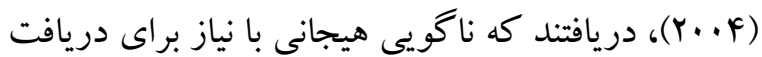

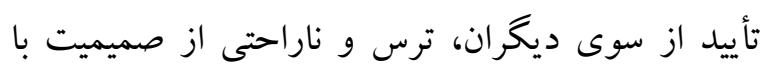

دلبستخى را در اختلالات شخصيت يذيرفتهاند كه مشكلات دلبستگى در اوايل كودكى مىتواند علت اصلى اختلالات شخصيت و نيز خودكشى باشد. سبككهاى دلبستگى از منابع درون فردى هستند كه مىتواند سطوح تنش و ناتوانى را در شرايط ناكوار تعديل كنند و اثرات منفى تنش را كمرنگك تر جلوه

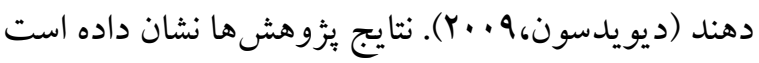
كه كاهش و يا عدم رابطه با والدين و عدم گفتخو با آنان

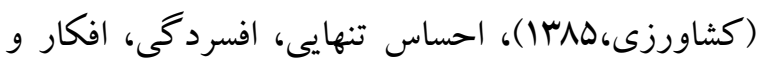

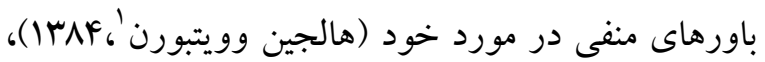

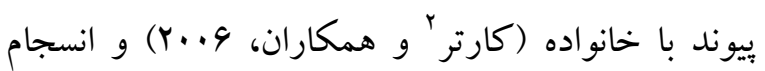

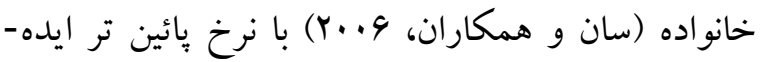
يردازى خود كشى رابطه داشتهاند و نرخ بالاى رفتارهاى خود كشى در افرادى كه در خانوادههاى آشفته زندگى بردى

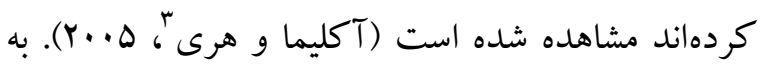

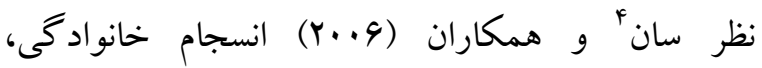
تعارضات و حمايت همسالان، نوع سبك دلبستكى افراد با والدين به صورت معنادارى بيشبينى كنندهى عزت نفس و افسردگى بودهاند كه از اين بين افسردگى عامل ميانجى قدرتمندى براى بيشبينى ايدهيردازى خود كشى

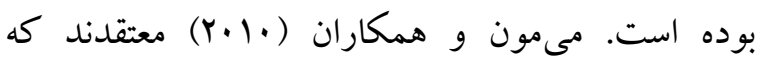
دلبستكى و حمايت خانواده در خود كشى تأثير دارد و بر نقش كنترل غيرمستقيم دلبستخى والد-كودكى در كاهش احتمال تلاشهاى خود كشى گرايانه تأكيد دارند نوجو انانى كه دلبستكى مثبت بهترى با والدينشان دارند كمتر در معرض خطر خودكشى قرار دارند.

\footnotetext{
1- Halgin \& Whitbourne

${ }^{2}$ - Carter

3- Akleema \& Hari

4. Sun
} 
سبك دلبستكى اجتنابى بيشتر است. با توجه به مطالب

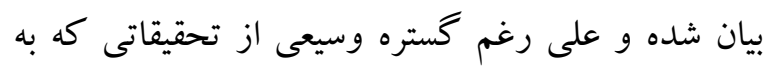
بررسى ابعاد گوناگون ناگويى هيجانى و سبك هاى

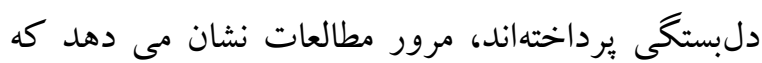
ناگويى هيجانى در بيماران افسرده و مضطرب بيشتر

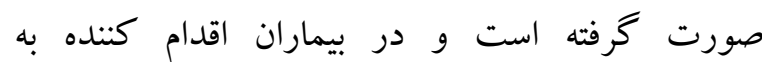
خود كشى تاكنون بززوهش مستقيمى صورت نخر فته است؛

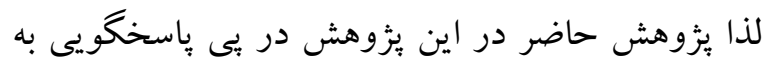

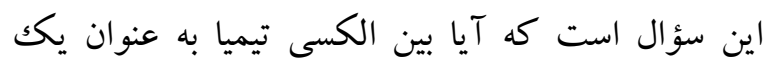
عامل درون فردى و سبك دل بستخى به عنوان يك عامل بين فردى در بيماران اقدام كننده به خودكشى و افراد بهنجار تفاوت وجود دارد؟

روش روش يُزوهش حاضر على - مقايسه اى از نوع پِس رويدادى است. جامعه آمارى يثزوهش حاضر شامل كليه افراد اقدام كننده به خودكشى شهرستان كنبد در سال 994 است كه به بيمارستان شهيد مطهرى اين شهر مراجعه كردند. همجينين افراد بهنجار جامعه شامل كليه

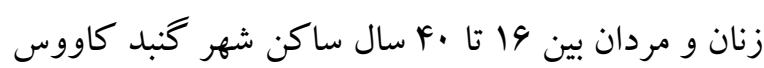
است. نمونه يُزوهش حاضر به دليل عدم دسترسى به آمار دقيق تعداد بيماران اقدام كننده به خود كشى . .انفر ( •ه بيمار اقدام كننده به خودكشى در بيمارستان و •له نفر

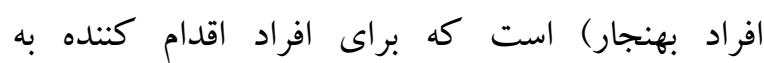
خود كشى در فاصله زمانى ا سال كليه افرادى كه اقدام به خود كشى كرده اند و توسط روان بز شكى خود كشى

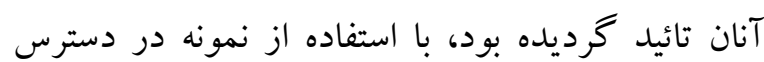

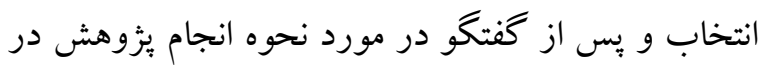
صورت تمايل فرد به سؤالات پِرسنامه پِاسخ دادند.
ديخران و عدم اهميت به روابط با ديخران ارتباط دارد.

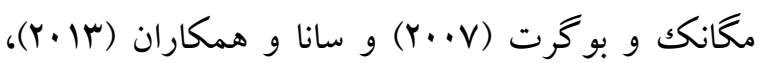
نشان دادند كه ناگويى هيجانى با سطح بايين عاطفه و

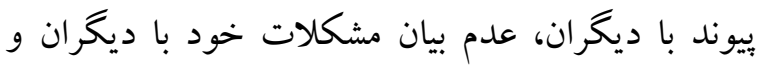
راهبردهاى مقابله اى نامناسب در موقعيتهاى بين فردى، مرتبط است كه كاهى ناتوانى منجر به خود كشى فرد مى شود. رابطه بين ناگويى هيجانى با افسردگى (بارباسيو و

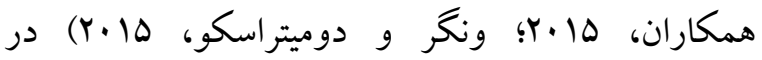
مطالعات بسيارى مورد تأييد قرار گرفته است. مرور يافته هاى اندكك ئزوهشى در زمينه رابطه بين ناكويى هيجانى و افسردگى به عنوان يكى از علل مهم خودكشى مبين شيوع بالاى ناگويى هيجانى (11 - 11 درصد) در ميان افراد افسرده است (بارباسيو و همكاران،

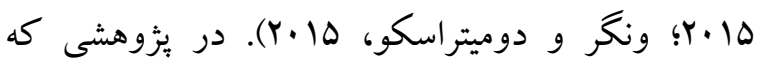
توسط وايس و همكاران (1999) انجام شد بيماران با ناكويى هيجانى سطوح بالاى اضطراب و افسردگى را

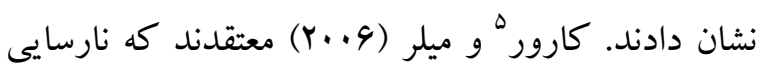
در تنظيم عواطف نقش مهمى در اختلالات خلقى دارند. بررسى نقش ناكويى هيجانى در اختلالات خلقى نه تنها

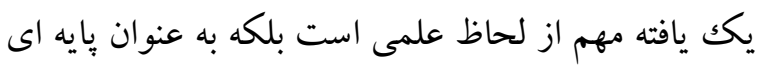
براى تحقيقات كاربردى در جهت شناسايى صفات شخصيتى مرتبط با مشكلات هيجانى به عنوان عوامل سهيم در بديدايى اختلالات خلقى مى تواند با آشكار

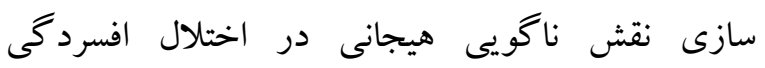
رهنمودى مناسب براى ييشگيرى و عدم تداوم اين اختلال باشد. در اين ئزوهش نشان داده شد كه نقص در بيان و تشخيص احساسات در رفتارهاى : برخطر از جمله خود كشى مؤثر باشد و ميزان خود كشى در افراد داراى

5- Carver 
نارسايى هيجانى و متغيرهاى فوق نيز معنادار بودند

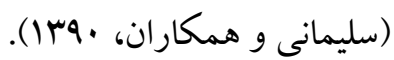
برسشنامه سبك دل دلبتكى هازن و و شيور: مقياس دلبستكى بزرگكالان كه با استفاده از مواد آزمون

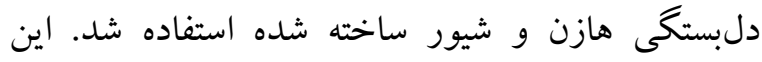
برسشنامه يك آزمون 10 سؤالى است و سه سبك سك

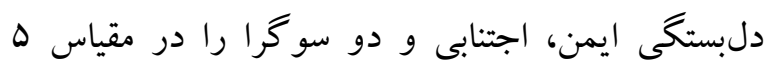

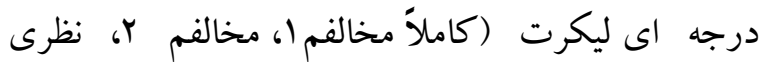

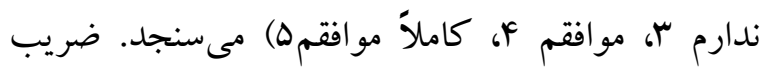
آلفاى كرونباخ به ترتيب براى دانشجويان دختر NY.

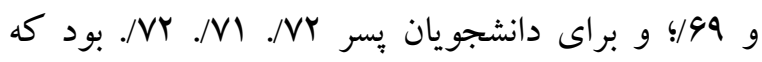
نشانه همسانى درونى مقياس دلبستگى بزرگك بـالان است. همجنين ضر ايب همبستخى بين نمرهى آزمودنى ها در دو نوبت، با فاصلهى دو هفته براى كل آزمودنى ها

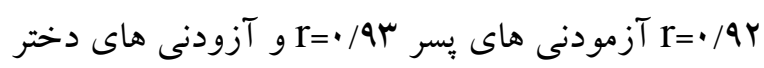

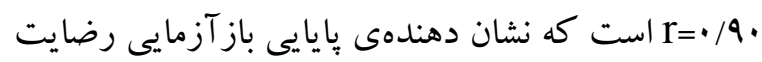

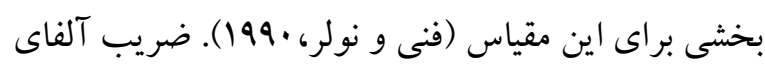
كرونباخ برسشهاى خرده مقياسهاى ايمن، اجتنابى و دو

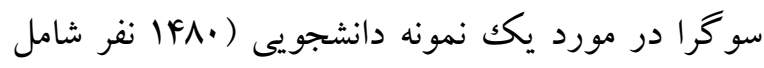

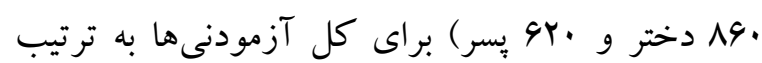

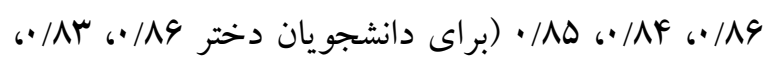

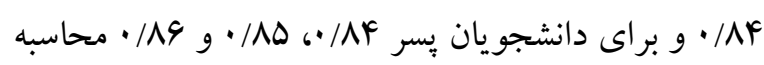
شد كه نشانه همسانى درونى خوب مقياس دلبستخى بـى بزرگك سال است. روايى بر اساس ضرايب توافت كندال

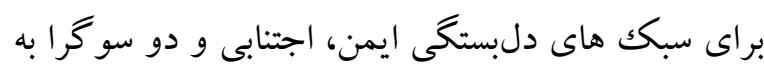

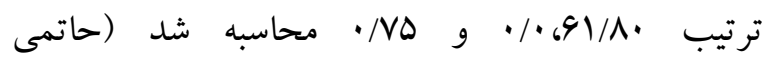

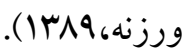

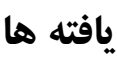

آزمودنى ها بر اساس سن و جنس همتا شده اند. ملاككهاى ورود شامل د داشتن سابقه خودكشى، محدودهى سنى 19 تا ·F سال، رضايت آكاهانه، عدم ابتلا به اختلال روانى ديخر و ملاككهاى خروج عدم

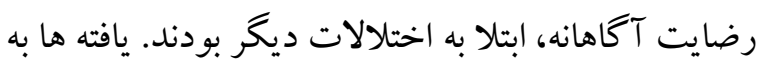
صورت گروهى و با شرط گمنامى مورد بررسى قرار

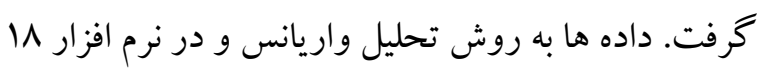
SPSS

ابزار يرسشنامه ناكويى هيجانى: اين مقياس در سال 1919

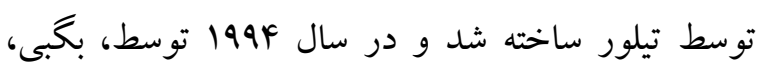
باكر و تيلور تجديد نظر گرديد و در بين روش هاى متفاوت سنجش ناكويى خلقى، براستفاده ترين و احتمالاً معتبرترين جبرسشنامه است. برسشنامه الكسى تيمياى

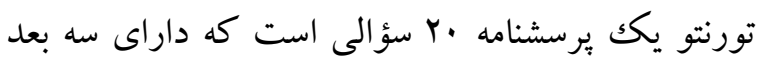

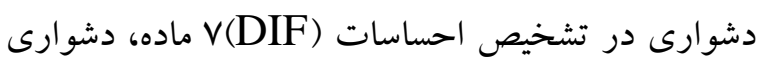
در توصيف احساسات (DDF) ه ماده و تمركز بر تجارب بيرونى (EOT) ^ ماده است. سؤالها بر حسب معيار ه نقطه اى ليكرت (از كاملاًٌ موافقم= 1 تا كاملاً مخالفم=ها) نمره كذارى مى گردند. روايى هم زمان مقياس نارسايى هيجانى، بر حسب همبستگى بين مقياس هاى اين آزمون و مقياس هاى هوش هيجانى و درماندگى مئى روان شناختى بررسى و مورد تائيد قرار گرفت. نتايج ضريب همبستخى بيرسون نشان داد كه بين نمره آزمودنى بروسي ها در مقياس نارسايى هيجانى كل با هوش هيجانى

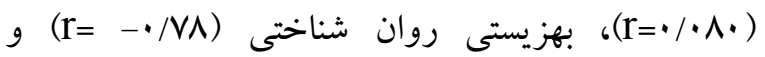

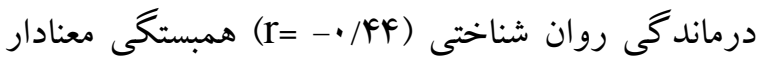
وجود دارد. ضرايب همبستكى بين زير مقياس هاى 
درصد) متأهل در گروه بيمار و در گروه بهنجار، Fا نفر

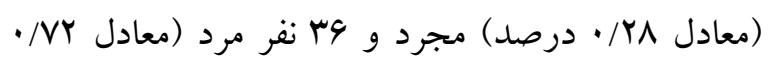
درصد) بوده اند. منظور بررسى سؤالات اين بثوهش،

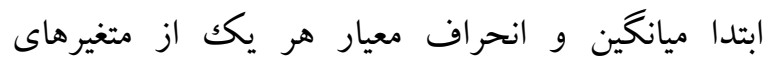
يزوهش محاسبه شد كه در جدول ا ارائه شده است.

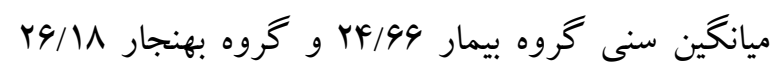

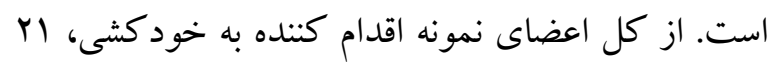

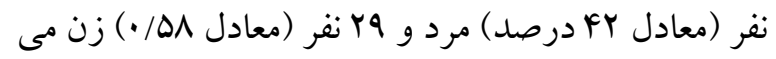

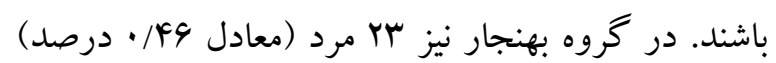
مرد و YV نفر (معادل OF/DF) زن شركت داشتند. همجنين

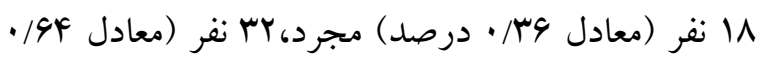

جدول 1 مقايسه تفاوت ميانكين نمره كل و خرده مقياس هاى الكسى تيميا

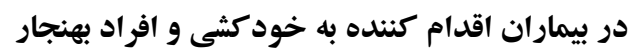

متغير

\begin{tabular}{|c|c|}
\hline & خود كشى \\
\hline ميانكين (انحراف & ميانكين (انحراف \\
\hline معيار) & معيار) \\
\hline$r / F$. & $r / 91$ \\
\hline
\end{tabular}

$(\cdot / 99 \Lambda) \quad(\cdot / \mathrm{V} 99)$

ناكويى هيجانى دشوارى در تشخيص احساسات

\begin{tabular}{|c|c|c|}
\hline $\begin{array}{l}r / F \Delta \\
(\cdot / \Delta F Q)\end{array}$ & $\begin{array}{l}r / F \Delta \\
(\cdot / \Delta F q)\end{array}$ & دشوار در توصيف احساسات \\
\hline $\begin{array}{l}r / T r \\
(\cdot / \Delta \wedge r)\end{array}$ & $\begin{array}{l}r / \cdot V \\
(\cdot / \Gamma 94)\end{array}$ & تمر كز بر تجارب \\
\hline $\begin{array}{l}r / M A \\
(\cdot / F G F)\end{array}$ & $\begin{array}{c}r / q . \\
(\cdot / \text { FAY FAr }\end{array}$ & نمره كل \\
\hline $\begin{array}{l}r / Y q \\
(\cdot / 4 q \cdot)\end{array}$ & $\begin{array}{l}r / A r \\
(\cdot / r V r)\end{array}$ & اجتابى \\
\hline $\begin{array}{c}r / M T \\
(\cdot / \Delta / F)\end{array}$ & $\begin{array}{l}r / v \cdot \\
(\cdot / F \mid \Delta)\end{array}$ & ايمن \\
\hline $\begin{array}{l}r / F Y \\
(\cdot / F \& Q)\end{array}$ & $\begin{array}{l}r / Y r \\
(\cdot / \Delta 99)\end{array}$ & دوسو مرا \\
\hline
\end{tabular}

نتايج تحليل واريانس در خصوص مقايسه ناكويى هيجانى بين دو گروه در جدول ب ارائه شده است. 
جدول r نتايج تحليل واريانس ناگويى هيجانى بين دو كروه

\begin{tabular}{|c|c|c|c|c|c|c|c|}
\hline توان & مجذور سهمى & معنادارى & ضريب & مجذانكين & آزادى درجه & مجذوروات & ناتويى هيجانى \\
\hline.$/ 99$ & $\cdot / \Upsilon \wedge$ & $.1 . \Delta$ & r/A9 & $19491 \cdot 1$ & 1 & 19491.1 & دشوارى در توصيف \\
\hline$\cdot / N \Delta$ & 1.9 & . & $1 / \Delta F$ & $r \cdot N / \Delta r$ & 1 & $r \cdot Q / \Delta r$ & دشوار در تشخيص \\
\hline$\cdot / \wedge \Delta$ & $1 / .9$ & $\cdot / 09$ & $\cdot / \Delta F$ & $r \cdot N / \Delta r$ & 1 & $r \cdot q / \Delta r$ & تمر كز بر تجارب \\
\hline$\cdot / 49$ &.$/ .4$ & $\cdot / \mathrm{AV}$ & .110 & $V r / 94$ & 1 & $V \Psi / Q 9$ & نمره كل \\
\hline \multicolumn{7}{|c|}{$\mathrm{P}<\cdot / \cdot I_{\text {، }} / A r_{6} \cdot / \Delta r$} & لامبداى ويلكس \\
\hline
\end{tabular}

مطابق با جدول r، تفاوت بين دو گروه در خرده مقياس به منظور بررسى معنادارى تفاوت ميانگين ها از آزمون دشوارى در توصيف احساسات معنادار است؛ اما در ساير تحليل واريانس استفاده شد. نتايج در جدول ب نمايش خرده مقياسها و نيز نمره كل الكسى تيميا تفاوت معنى داده شده است.

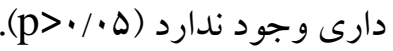

\begin{tabular}{|c|c|c|c|c|c|c|c|}
\hline توان & مجذور سهمى & معنادارى & ضريب & مجذذورات ميانكين & آزادى درجه & مجذوروات & سبك دل بستكى \\
\hline$\cdot / 99$ & $\cdot / T \Delta$ &.$/ .1$ & rY/GF & $V r / 99$ & 1 & $\mathrm{Vr/a9}$ & سبك دلبستكى اجتنى \\
\hline$\cdot / 79$ &.$/ .1$ & $\cdot / 19$ & $r \mid / F$ & $99 / 11$ & 1 & $99 / 11$ & سبك دل بستكى \\
\hline$\cdot / \wedge \Delta$ & .1 .9 & $\% r$ & $9 / \Gamma 1$ & $r \cdot N / \Delta r$ & 1 & $r \cdot Q / \Delta r$ & سبك دوسو بستكى \\
\hline
\end{tabular}

بر اساس نتايج به دست آمده تفاوت دو گروه در مؤلفه دشوارى در تشخيص احساسات ناكويى هيجانى معنادار

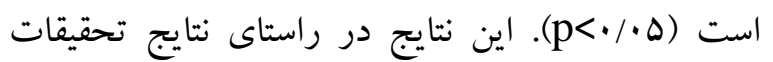

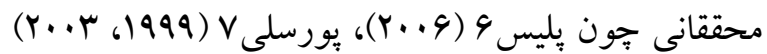
و شاهقليان (Y.V.V) همسو است. ساليمنن و و تويكا

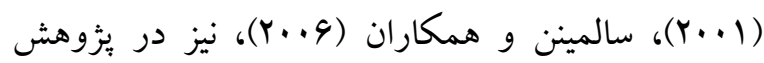

نتايج جدول ب حاكى از معنادارى تفاوت بين دو گروه در سبك دلبستگى اجتنابى و ايمن است. با توجه به نمرات جدول Yميانگين نمره سبك دلبستكى اجتنابى در اقدام كنند گان به خود كشى كمتر از گروه سالم است؛ اما اين تفاوت در سبك دلبستخى دوسو گر ا معنادار نيست. 
شناسايى و ابراز احساس ارتباط دارد. ارتباط بين ارزيابى

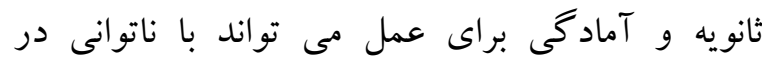

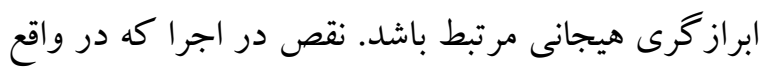
علامت مشخص ناكويى هيجانى است به عاطفه سطحى، تظاهرات هيجانى معيوب، بدكاركردى در ابراز هيجان، زبان و حر كات بيانگر جهره اي نامتناسب منجر مى شود. به. اين امر مى تواند در درازمدت افراد را دجار خستخى روانى كرده و زمينه ساز بروز اقدام به خود كشى در آنان شود، به اين صورت كه دشوارى در تنظيم احساسات

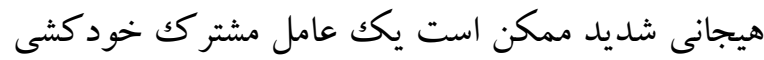

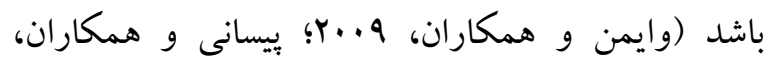
rا (Y). در تبيين اين يافته همجنين مى توان به ارتباط بين اقدام به خود كشى و حوزه هاى خاص تنظيم احساسات و به طور ويزه عدم يذيرش و بروز تكانه ها اشاره كرد

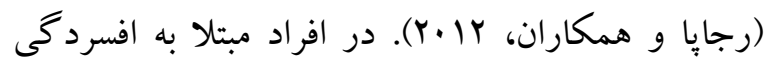
مشكل در تنظيم احساسات با رفتارهاى وابستگى رهى

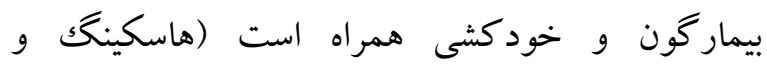

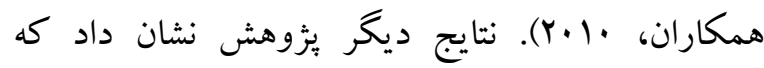
همجنين در سبك دلبستگى تفاوت به دست آمده بين

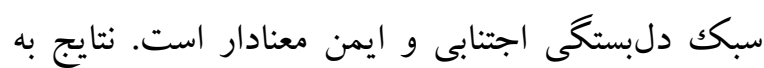
دست آمده با نتايج مطالعات كه حاكى از نقش خانواده در نقش والد اوليه و خانواده را در بروز خودكشى نشان داده اند، همسو است. براى مثال بيوند اعضاى خانواده

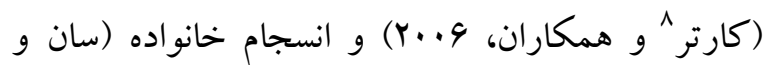

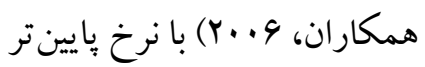

ايدهيردازى خودكشى رابطه داشتهاند و نرخ بالاى رفتارهاى خود كشى در افرادى كه در خانو ادههاى آشفته زندكى كردهاند مشاهده شده است (آكليما و هرى،
خود نشان دادند كه ويز گیى شخصيتى برون كرايى با ناكويى هيجانى رابطه منفى معنادار دارد. نورى، آشتيانى،

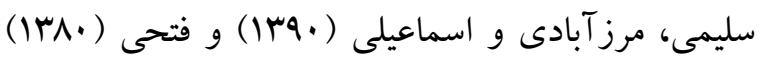
در ئزوهش خود نشان دادند ميزان خودكشى در افراد درون گرا بيشتر از شخصيت برونگرا است. در تبيين اين يافته مى توان كفت كه دشوارى در بيان احساسات و سركوب هيجانى مى تواند منجر به تشديد افسردگى و افكار منفى شود و در دراز مدت مى تواند افكار خودكشى را تشديد كند. به نظر مى رسد افسردگى ممكن است بين افكار و رفتارهاى خود كشى نقش مهمى داشته باشد (دبرارديستال، IV +Y). اين ناتوانى را مى توان از يكك سو محصول كنش ورى بهنجار سيستم يردازش شناختى اطلاعات هيجانى و از سوى ديخر به توان تنظيم و مديريت هيجانها نسبت داد كه فرايند عملى سازى احساسات و هيجانها را در سطح رفتارهاى شخصى و تعامل هاى بين شخصى تقويت مى كند. ضعيف بودن مديريت هيجانها منجر به افزايش رفتارهاى برخطر از جمله خود كشى مى شود. برارديس و همكاران (rا.ب) در بززوهش خود كزارش دادند كه مشكل در شناسايى و توصيف احساسات به طور قابل توجهى با افسردگى همر اه بود. بارها مشاهده شده است كه يكك سابقه مشترك در افكار و رفتارهاى خودكشى، تجربه بريشانى عاطفى بوره غيرقابل كنترل است (دوور، || (Y). علاوه بر اين، افرادى كه در تنظيم سطح بالايى از بريشانى عاطفى مشكل بيشترى دارند، بيشتر جان خود را توسط خودكشى از دست مى دهند. (ييسانى و همكاران، سا.ب(). رفتار خود كشى با راهكارهاى ناساز گار براى تنظيم هيجان همراه بوده است (هريس و همكاران،ش|+r). ارتباط نادرست بين فراخوان و ارزيابى محركك هيجانى، با 
افراد با سبك دلبستخى ايمن عواطف منفى كمترى را

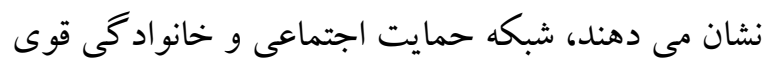
دارند و راهبردهاى مقابلهاى مسئله مدار از خود نشان مى دهند.

\section{نتيجه كيرى}

به طور كلى مى توان بيان كرد كه دشوارى در تشخيص احساسات، ناگويى و مشكلات تنظيم هيجانى مى تواند سبب افزايش اختلالات روانى باشد. تشديد اختلالات روانى در افراد مى تواند شيوع خودكشى و اقدام به خود كشى را افزايش دهد. برنامه هاى مداخلاتى با هدف بهبود تنظيم هيجانى مى تواند منجر به كاهش شيوع اين اختلالات شود. برخوردارى از شبكه حمايت اجتماعى و خانوادگى قوى و راهبردهاى مقابلهاى مسئله مدار،

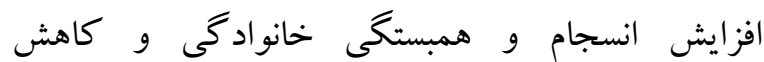
تعارضات با همسالان در كاهش اقدام به اين رفتار از نقش مؤثرى برخوردار است. نتايج اين تحقيق به دليل استفاده

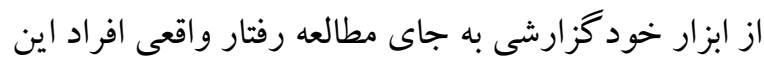
يثوهش را در تعميم نتايج با محدوديت مواجه كرد. استفاده از روش نمونه گيرى در دسترس، از ديخر محدوديت هاى اين بثوهش است. بيشنهاد مى شود، بررسى ساير عوامل هيجانى مانند نقص در بردازش اطلاعات شناختى و هيجانى و همجينين بررسى سهم عوامل بين فردى در بروز اقدام به خود كشى مورد بررسى بيشتر قرار گيرد تا بتوان به كنترل بيشتر اين بحران بردي اجتماعى و فردى كمكك نمود.

\section{سياسگز ارى}

نو يسند كان مقاله مراتب تشكر و قدردانى خود را از كليه افراد شر كت كننده در اين بثزوهش ابراز مى نمايند.

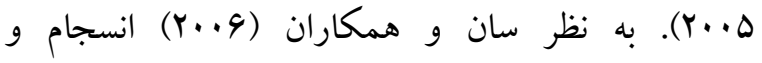
همبستگى خانوادگى، تعارضات و حمايت همسالان به ونه صورت معنادارى ييشبينى كنندهى عزت نفس و و افسردگى بودهاند كه از اين بين افسردگى عامل ميانجى قدرتمندى براى بيشبينى ايدهيردازى خودكشى بوده

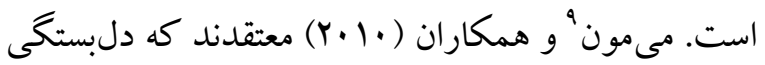
و حمايت خانواده در خودكشى تأثير دارد و بر نقش كنترل غيرمستقيم دلبستگى والد-كودكى در كاهش احتمال تلاشهاى خودكشى گرايانه تأكيد دارند. براى تبيين نتايج مىتوان گفت كه عوامل خانوادگى ذكر شده

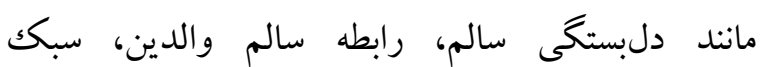
فرزنديرورى، وجود همبستگى در خانواده و رابطه سالم بين والدين و رابطه آنها با فرزندان و سلامت روان والدين و ساير عوامل ذكر شده يشتوانه نظرى قوىاى دارند كه مىتوانند بر سلامت روانى و جسمانى فرزندان تأثير بكذارند. نوجوانانى كه دلبستخى مثبت بهترى با بـا والدينشان دارند كمتر در معرض خطر خودكشى قرار

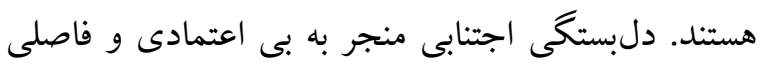

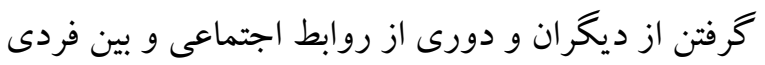

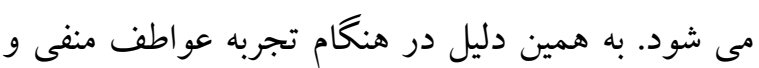
استرس فاكتورهاى گوناكون فرد قادر به يافتن راه حل و كمكك از جانب ديخران نيست؛ لذا عدم تنظيم هيجانى خود مى تواند زمينه ساز بروز اختلالات روانى و جسمى شود. نداشتن شبكه حمايت اجتماعى قوى خود مى تواند زمينه ساز بروز انواع اختلالات روانى و رفتارهاى تكانه اى ماند اقدام به خودكشى باشد. بى اعتمادى و فاصله كرفتن از ديخران مى تواند احتمال بروز پِاسخ هاى مقابله اى ناكار آمد را افزايش دهد (بشارت، سهبا). در مقابل 


\section{References}

Abdul Kadir NB, Bifulco A. (2013). Insecure attachment style as a vulnerability factor for depression: Recent findings in a communitybased study of Malay single and married mothers. Psychiatry Research, 210(3), 919924.

Agriculture, M Ali. (2006). Youth and Youth Issues, Tehran: Roozbehan Publications \{In persian\}.

Akcan R, Arslan MM, Çekin N, Karanfil R. (2011). Unexpected suicide and irrational thinking in adolescence: A case report. Journal of Forensic and Legal Medicine, 18(6):288-290.

Akleema A, Hari DM. (2005). Social predictor of suicidal behavior in adolescents in Trinidad and Tobago. Social psychiatry and psychiatric epidemiology. 40 (3); 186-191.

Barbasio C, Vagelli R, Marengo D, Querci F, Settanni M, Tani C, Mosca M, Granieri A. (2015). Illness perception in systemic lupus erythematosus patients: The roles of alexithymia and depression. Comprehensive Psychiatry, 63: 88-95.

Besharat M A, Geranmayeh poor Sh, Poor Naghad Ali A, Ofoghi Z, Habibnezad M, Aghaei sabet $\mathrm{S}$ Z (1393). The Relationship between Emotional Cognition and Interpersonal Behaviors: The Pivotal Role of Attachment Styles, Contemporary Psychology,9(1),3$16\{$ In persian $\}$.

Besharat M A. (1387). Emotional insufficiency and defensive style, Journal of Mental Health Principles, 10(3), 181-190 \{In persiaon\}.

Besharat M A. (1391). The moderating role of attachment styles in the use between emotional arousal and marital satisfaction Journal of Mental Health Principles, Vol (4)14,324-335 \{In persian $\}$

Bowlby J. (1969). Attachment. New York: Basic Books.

Brezo J, Paris J, Turecki G. (2006). Personality traits as comelates of suicidal ideation, suicide attempts, and suicide completions: a systematic review. Acta Psychiatrica Scandinavica. 113 (3); 180206.
Brown RJ, Bouska JF, Frow N, Kirkby A, Baker GA, Kemp S, Bumess C, Reuber M. (2013). Emotional dysregulation, alexithymia and attachment in psychogenic nonepileptic seizures. Epilepsy \& Behavior, 29(1): Pages 178-183.

Campanella S, Falbo L, Rossignol M, Grynberg D, Balconi M, Verbanck P, Maurage P. (2012). Sex differences on emotional processing are modulated by subclinical levels of alexithymia and depression: A preliminary assessment using event-related potentials. Psychiatry Research. 197(1-2): 145-153.

Cantor CH. (2000). Suicide in the Weston World.In K. Hawton< K.V.Heeringen (Eds.). The intemational handbook of suicide and parasuicide. Chichester.John Wiley \& Sons.

Carter M, McGee R, Taylor B, \& Williams S. (2006). Health outcomes in adolescence: Associations with family,friends and school engagement. Joumal of Adolescence, 30(1), 51-62.

Giner L, Blasco-Fontecilla H, Mercedes PerezRodriguez M, Garcia-Nieto R, Giner J, Guija JA, Rico A, BarreroE, Luna MA, de Leon J, Oquendo M A, Baca-Garcia E. (2013). Personality disorders and health problems distinguish suicide attempters from completers in a direct comparison. Joumal of Affective Disorders, 151(2):474-483.

Gordon KW. (2008). The multidimensionality of peer victimization and patterns of elating in attachment.Ph.D. Dissertation. USA: University of Mississippi, 15-28.

Grunebaum MF, Galfalvy HC, Mortenson LY, Burke AK, Oquendo MA, Mann JJ. (2010). attachment and social adjustment: Relationships to suicide attempt and major depressive episode in a prospective study. Joumal of Affective Disorders, 123 (1-3), 123130.

Halligan R P, Crosby Whitburn S. (1384). Psychopathology. Translated by Seyyed Mohammadi, Yahya. Psychological publication. Tehran\{In persian\}.

Harris L, Chelminski L, Dalrymple K, Morgan TH, Zimmerman M. (2018). Suicide attempts and 
emotion regulation in psychiatric outpatients, Journal of Affective Disorders, 19:1-20.

Hatami varzaneh A. (1389). The mediating role of attachment style in the relationship between parenting style and marital commitment in married students of Allameh Tabatabai University. Masters Degree in Family Counseling, Allameh Tabatabai University\{In persian\}.

Hemming L, Taylor P, Haddock G, Shaw J, Pratt D. (2019). A systematic review and meta-analysis of the association between alexithymia and suicide ideation and behaviour, Joumal of Affective Disorders, (19)34-82.

Huisman A, Cornelis AJ, Houwelingen V, Kerkhof JFM. (2010). Psychopathology and suicide method in mental health care. Journal of Affective Disorders. 121 (1-2): 94-99.

Jones BDM, Chopra KK, Grummitt J, Ravindran A, Levitan RD. (2014). Attachment style at discharge predicts depression status four months following a 28-day alternate-milieu inpatient program. Asian Journal of Psychiatry, 8:104-105.

Karukivi M, Tolvanen M, Karlsson L, Karlsson H. (2014). Is alexithymia linked with marital satisfaction or attachment to the partner? A study in a pregnancy cohort of parents-to-be. Comprehensive Psychiatry, 55 (5), 12521257.

Kering A, Deividson C, Teil C, Janson SH L. (1391). Psychopathology. Translated byShamsipour, Hamid. Honorable Publications. Tehran \{In persian\}.

Koldi A, Gravand A. (2002). Investigating the Causes of Suicide in Kouhdasht County, 2 (6): 295295\{In persian\}.

Kulkami RR, Nagaraja Rao K, Begum S. (2013). Comorbidity of psychiatric and personality disorders in first suicide attempters: A casecontrol study. Asian Journal of Psychiatry. 6 (5):410-416.

Li S, Zhang B, Guo Y, Zhang J. (2015). The association between alexithymia as assessed by the 20 item Toronto alexithymia Scale and depression: A meta-analysis. Psychiatry Research, 227(1); 1-9.

Loas G, Dalleau E, Lecointe H, Yon V. (2016). Relationships between anhedonia, alexithymia, impulsivity, suicidal ideation, recent suicide attempt, C-reactive protein and serum lipid levels among 122 inpatients with mood or anxious disorders, Psychiatry Research,15:1-25.

Maimon D, Browing CR. (2010). Understanding socializing, collective efficacy and violet behavior among urban youth. Criminology; $48(20) ; 443-474$.

Mazaheri M, Afshar H, Mohammadi N. (2011). Alexithymia and Gastrointestinal Disorders, Behavioral Sciences Research, (2011), 9 (5): 273-381\{In persian\}.

Mohammadkhani Sh, Farajad M. (1388). The relationship between metacognitive beliefs and thought control strategies with obsessivecompulsive symptoms in a nonclinical population,1(3),35-51 \{In persian $\}$.

Montebarocci O, Codispoti M, Baldaro B, \& Rossi N. (2004). Adult attachment style and alexithymia. Personality and Individual Differences, 36, 499-507.

Moradi A, Akbari Zardkhaneh S, Cheraghi F, Fooladvand Kh. (2009). The effect of family structure and social support on student suicide. Research Family, Fifth Year, No. 20, Winter, 482-487\{ In persian\}.

Na KS, Oh SJ, Jung HY, Lee SI, Kim YK, Han C, Ko YH, Paik JW, Kim SG. (2013). alexithymia and low cooperativeness are associated with suicide attempts in male military personnel with adjustment disorder: A case-control study. Psychiatry Research, 205 (3), 220-226.

Nahrangi S. (2012). Comparison of Emotional Consciousness and Resilience of Depressed and Normal Individuals, MSc in Clinical Psychology, Islamic Azad University, Sari Branch \{In persian\}.

Ozouni Davaji RB, Valizadeh S, Nikamal M. (2010). The relationship between attachment styles and suicide ideation: the study of Turkmen 
students, Iran. Procedia - Social and Behavioral Sciences, 5: 1190-1194.

Peles E, Schreiber S, Adelson M. (2006). Variables associated with perceived sleep disorders hn methadone maintenance treatment (MMT). Patients. Drug and Alcohol Dependency, 82; 103-110

Perkins DF, \& Hartless G. (2002). An ecological riskfactor examination of suicidal ideation and behavior in adolescent. Joumal of Adolescent Research, 17, 3-26.

Ramazani V, Shams Esfandabadi H, Tahmasebi Sh. (1386). Investigating the Emotional Consequences of Attachment Styles in Students. Research in Psychological Health, 38,1-47\{In persian\}.

Roy A, Sar chiapone M, Carli V. (2007). Low Resilience in suicide Attempters: Relationsh ip to depressive symptoms. Joumal of Depression and Anxiety, 24: 273-274.

Sadock BJ, Sadock VA. (2011). Clinical psychiatry: Kaplan \& Sadocks synopsis of psychiatry. Behavioral sci 10th ed, Lippincott Williams \& Willkins.

Shahgholiyan M, Moradi A, Kafi S M. (1386). The Relationship between Alexithymia and Emotional Behaviors and General Health of Students, Iranian Joumal of Psychiatry and Clinical Psychology,13(3),238-248\{In persian\}.

Soleimani E, Zahedbabolan A, Farzaneh J A, Sotodeh M B. (1390). Comparison of Emotional Failure and Social Skills in Students with Normal and Learning Disorders, 1(1),78-93 \{In persian $\}$.

Sun RC, Hui EK, \& Watkins D. (2006). Towards a model of suicidal ideation for Hong Kong Chinese adolescents. Joumal of Adolescence, 29(2), 209-24.

Taylor GJ. (2000). Recent developments in alexithymia theory and research. Canadian Joumal of Psychiatry, 45:134-42.

Vengher I, Dumitrascu DL. (2015). The relationship between alexithymia, depression and quality of life in patients with functional dyspepsia.
Joumal of Psychosomatic Research, 2015; 78(6): 629.

Wedig MM, Frankenburg FR, Reich DB, Fitzmaurice G, Zanarini MC. (2013).Predictors of suicide threats in patients with borderline personality disorder over 16 years of prospective follow-up. Psychiatry Research, 208(3):252-256.

Wise TN, Mann LS. Shay L. (1992). Alexithymia and the five-factor model of personality. Comprehensive Psychiatry, 33: 147-151. 